\title{
Patologia wladzy*
}

We współczesnym rozumieniu dezorganizacji społecznej bądź patologii społecznej zawarte sa elementy różnych koncepcji ${ }^{1}$, zwłaszcza zwiazanych $z$ teoria kontroli społecznej i syndromem deprywacji. Przyjmuje się, że dezorganizacja (patologia) społeczna to stan zakłócenia równowagi społecznej, który charakteryzuje osłabienie więzi społecznych, systemu norm i wartości społecznych oraz rozregulowanie mechanizmu społecznej kontroli. .

Dezorganizacja społeczna nasila się w sytuacji nierównomiernego rozwoju ekonomicznego, społecznego, politycznego i kulturowego (syndrom zmiany społecznej) naruszającego istniejący ład społeczny. Ład społeczny - charakteryzujący się spójnością norm i uznawanych wartości oraz prawidłowym funkcjonowaniem podstawowych instytucji społecznych - to raczej kategoria rozważań teoretycznych i rzeczywistości wirtualnej niż stan istniejący we współczesnym świecie. Dlatego też termin „dezorganizacja społeczna" określa nie tyle stan rzeczy, ile zjawisko stopniowalne: proces narastania przypadków naruszeń norm społecznych prowadzących do ogólnego rozkładu instytucji regulujących zachowania jednostkowe i grupowe.

\footnotetext{
* Przedruk z: M. Jarosz, Władza, przywileje, korupcja, Wydawnictwo Naukowe PWN, Instytut Studiów Politycznych PAN, Warszawa 2004, s. 41-51.

1 Wywodzących się z teorii Émile'a Durkheima, Roberta K. Mertona, Ruth Rosner Kornhauser $\mathrm{i}$ innych. W Polsce pierwszą książką poświęconą dezorganizacji społecznej była praca Adama Podgóreckiego Patologia życia społecznego (Państwowe Wydawnictwo Naukowe, Warszawa 1969), a pierwsza publikacja, w której analizowano procesy dezorganizacji na podstawie polskich źródłowych materiałów statystycznych była praca zbiorowa pod redakcja Marii Jarosz Wybrane zagadnienia patologii społecznej (Główny Urząd Statystyczny, Warszawa 1975).
} 
Wzrost liczby negatywnych zachowań społecznych wskazuje na względną dewaluację systemu obowiąujących nakazów i zakazów społecznych. Trendy rozwojowe zjawiska sa wskaźnikiem strukturalnych zakłóceń w funkcjonowaniu społeczeństwa ${ }^{2}$.

Doświadczenia kilkunastu lat transformacji wskazuja trwałość mechanizmu narastania zjawisk dezadaptacyjnych towarzyszacych transformacji systemowej, i to we wszystkich krajach postkomunistycznych. Dotyczy to nasilania się przejawów jednostkowych i grupowych postaw i zachowań społecznych sprzecznych $z$ obowiąujacym oraz społecznie akceptowanym systemem norm i wartości. Jednak nie tylko. Znamiona dezorganizacji społecznej moga przejawiać również (a, jak wskazuja doświadczenia III Rzeczypospolitej, istotnie przejawiaja) instytucje gospodarcze, polityczne, społeczne, administracyjne - ponieważ „nie tyle "źli ludzie» sa źródłem "złych zachowań", ile [...] pewne instytucje, pewne organizacyjne konstrukcje społeczne przez swą strukturę i rozlokowanie pozycji i ról moga indukować i produkować zachowania społecznie negatywne"2.

Instytucjonalne rodzaje dezorganizacji społecznej wynikaja $z$ dysfunkcji władzy ustawodawczej (uregulowania prawne nieadekwatne do potrzeb gospodarczych i społecznych, zła jakość aktów prawnych) i wykonawczej (niekompetencja, partykularyzm, klientelizm, korupcja).

Dysfunkcja instytucji publicznych i patologia władzy, której najbardziej spektakularnym przejawem jest korupcja, nie sa rzeczą nową. Występowały „od zawsze”, w niemal każdym kraju, ale w zróżnicowanym zakresie i w różnym natężeniu. W PRL-u korupcjogenny był sam system niedoborów rynkowych i sposób osiągania dóbr trudno dostępnych. Zadziwiająco szeroki zasięg miała patologia instytucjonalna ${ }^{3}$.

Naonczas - i w latach solidarnościowej rewolucji - powszechne były nadzieje, że oczekiwane zmiany spowoduja nie tylko wzrost

\footnotetext{
2 A. Podgórecki, Patologia działania instytucji, w: Zagadnienia patologii społecznej, w: idem (red.), Państwowe Wydawnictwo Naukowe, Warszawa 1976, s. 180.

3 Zob. szerzej K. Daszkiewicz, Traktat o złej robocie, Ksiażka i Wiedza, Warszawa 1984; M. Jarosz, Disfunctions of Enterprises in Etiology of Economic Crimes, „Eurocriminology” 1990, t. 3.
} 
zarobków (i pełne półki towarów w sklepach), ale także likwidację kolejek w urzędach, łapówek i arogancji władzy. Transformacja i prywatyzacja miały być czymś w rodzaju magicznego zaklęcia, które skłoni urzędników do udzielania pomocy ludziom tylko dlatego, że będą do tego zobowiazani i za to opłacani ${ }^{4}$. „Zakładałem - pisał Andrzej Osęka - że gdy Polska odzyska wolność, gdy system nakazowo-rozdzielczy zostanie zastapiony przez wolny rynek, znikną urzędy $z$ mrowiem pasożytów wyciagających łapę do petenta. Przyjda ludzie nieprzekupni, myślący w kategoriach obywatelskiego obowiązk"

Tymczasem niewiele się zmieniło: tyle tylko, że można pisać i nagłaśniać systemowe nieprawidłowości. Skądinąd powszechne niedocenianie roli wolnej prasy wydaje się ulegać stopniowej weryfikacji. Zwłaszcza w latach 2001-2003, kiedy dzięki prasie, radiu i telewizji ujawniono największe afery III Rzeczypospolitej. Jednym $z$ podstawowych warunków należytego funkcjonowania państwa i gospodarki jest sterowanie nimi przez ludzi „w szerokim rozumieniu kompetentnych (wiedza, doświadczenie, charakter, charyzma osobista itp.), a następnie poddanie ich takiemu mechanizmowi kontroli, który zapewni, że będą działać zgodnie $z$ interesem publicznym". Chodzi tu o kontrolę społeczna rozumiana jako sposób „oddziaływania na zachowania wykraczające poza granice społecznej tolerancji lub [...] zapobiegajacych pogwałceniom reguł społecznych"7. Sa to jednak wymagania raczej teoretyczne, w praktyce owi zbiorowi aktorzy sceny politycznej i gospodarczej, którym stanowiska przypadły jako łup polityczny należny zwycięskiej partii, sa mało efektywni, zachłanni i niezdyscyplinowani. Kontrolę społeczna - która jest przecież warunkiem sine qua non

\footnotetext{
${ }_{4}$ Zob. B. Lewenstein, B. Pawlik (red.), A miało być tak pięknie... Polska scena publiczna lat dziewięćdziesiatych, Uniwersytet Warszawski, Instytut Stosowanych Nauk Społecznych, Warszawa 1994.

5 A. Osęka, Potrzebujacy bardziej, „Gazeta Wyborcza”, 5-6 lipca 2003.

6 A.Z. Kamiński, Dwa systemy - dwie ordynacje. Polityczne i społeczne implikacje wyboru ordynacji wyborczej, Centrum im. Adama Smitha, Warszawa 2000, maszynopis powielony, s. 9.

7 A. Kojder, Godność i siła prawa, Oficyna Naukowa, Warszawa 2001, s. 261.
} 
funkcjonowania demokracji i ważnym elementem gospodarki rynkowej - zastępują $z$ reguły działania pozorne, na przykład roszady stanowisk. Tak określa się mająca szeroki zakres (i reperkusje społeczne) praktykę odwoływania $z$ posad ludzi jednej opcji politycznej i zastępowania ich innymi, związanymi silniej $z$ nowym zwycięskim ugrupowaniem ${ }^{8}$.

Ustalenia Okragłego Stołu oraz przemiany społeczno-polityczne po 1989 roku nie zachwiały raczej wpływami służb specjalnych w budującej swoje podstawy III Rzeczypospolitej. Co więcej, mimo braku większości dokumentów archiwalnych uprawniona jest teza, że już w drugiej połowie lat osiemdziesiatych wielu przedstawicieli wojskowych i cywilnych służb specjalnych rozpoczęło przygotowania do organizacyjnych i ekonomicznych podstaw funkcjonowania w nowej rzeczywistości ${ }^{9}$. Sprzyjały temu: wiedza o realiach gospodarczych, kontakty z Zachodem (gospodarcze, towarzyskie, finansowe), wpływ na decyzje gospodarcze, a także sprawność organizacyjna. W wyniku reorganizacji służb specjalnych po 1989 roku ich szeregi opuściło około 15 tys. pracowników, których znaczna część natychmiast zaczęła funkcjonować w nowej rzeczywistości gospodarczej, między innymi jako współwłaściciele firm polonijno-zagranicznych, indywidualni importerzy deficytowych towarów oraz przedstawiciele wielu central handlu zagranicznego. Oficerowie służb specjalnych odegrali również znacząca rolę w prywatyzacji szeregu dziedzin życia gospodarczego i tworzeniu nowych sektorów, na przykład funduszy inwestycyjnych, banków, wprowadzaniu branży nowych technologii (zwłaszcza teleinformatycznych) oraz $\mathrm{w}$ obrocie specjalnym ${ }^{10}$.

\footnotetext{
8 Jakkolwiek zasięg owych przetasowań jest rozmaity. Najdalej idące charakteryzowały rządy koalicji Akcja Wyborcza Solidarność - Unia Wolności. Ten awuesowski zwłaszcza skok na posady i kasę w myśl hasła TKM („teraz, k..., my”) był zaiste niezwykle konsekwentny. Kolejna rządzaca koalicja (Sojusz Lewicy Demokratycznej - Unia Pracy - Polskie Stronnictwo Ludowe) przejęła fatalne standardy działań swoich poprzedników.

9 Zob. szerzej A. Zybertowicz, W uścisku tajnych służb: upadek komunizmu i układ postnomenklaturowy, Wydawnictwo Antyk, Komorów 1993 oraz idem, Paradoksy niewiedzy $i$ ukryci aktorzy, „Ius et Lex” 2003, nr 1.

${ }^{10} \mathrm{Na}$ temat skali zjawiska zob. Informacja statystyczna o sprawach karnych, wszczętych $i$ prowadzonych $w$ prokuraturach wojskowych $w$ latach 1998-2003 o przestępstwach o tzw.
} 
Taka sytuacja doprowadziła do ukształtowania się silnej sieci powiąań personalnych opartych na przywilejach oraz zagwarantowała wysoka pozycję materialną wynikająca najczęściej $z$ nieformalnych i często korupcjogennych układów.

Można także zaobserwować tworzenie nowych mechanizmów owych niejasnych powiązan, często obudowanych normami prawnymi lub decyzjami administracyjnymi. Ich przykładem jest obszar ochrony informacji niejawnych opanowany przez byłych oficerów Urzędu Ochrony Państwa i Wojskowych Służb Informacyjnych, a także obecność byłych oficerów służb specjalnych w firmach lobbingowych i wywiadowniach gospodarczych. Wpływy te sa oparte na sieci nieformalnych powiązań ze światem polityki i biznesu, czego skutkiem jest realizacja interesów grupowych $-z$ reguły ze szkodą dla państwa i gospodarki. Jeśli prawda jest to, że: „Czwarta władza w państwie nie sa żadne media, tylko służby specjalne. Służby specjalne pracuja dla siebie. Ich nadrzędnym celem jest ciche sprawowanie władzy. To one mianuja ministrów albo ich utracaja" ${ }^{11}$, to uzasadnione staje się podejrzenie Andrzeja Zybertowicza, że "sa układy, na które praktycznie nie ma mocnych"12, a rzady prawa staja się $\mathrm{w}$ istocie fasada bezprawia.

Polska nie jest tu wyjątkiem. We wszystkich państwach postkomunistycznych, również w krajach Starego Kontynentu, w Stanach Zjednoczonych oraz w innych państwach i państewkach obserwuje się wzmożona aktywność służb specjalnych. Ich dwutorowe uwikłanie $\mathrm{w}$ gospodarkę i politykę wszędzie pociaga za soba jednoznacznie negatywne konsekwencje dla państwa. Sa one proporcjonalne do zasięgu owych patologicznych działań. Kontrolę społeczną sprawuja najczęściej media, wyciągające na światło

charakterze korupcyjnym, Naczelna Prokuratura Wojskowa, Warszawa, luty 2004; zob. także M. Jędrzejko, Analiza działań byłych funkcjonariuszy służb specjalnych w gospodarce, Instytut Studiów Politycznych PAN, Warszawa 2003, maszynopis.

${ }^{11}$ Jerzy Dziewulski w rozmowie z Krzysztofem Różyckim, „Angora”, 14 grudnia 1997.

12 A. Zybertowicz, Demokracja jako fasada: przypadek III R.P., w: A. Kojder, K. Z. Sowa (red.), Los $i$ wybór. Dziedzictwo i perspektywy społeczeństwa polskiego, Wydawnictwo Uniwersytetu Rzeszowskiego, Rzeszów 2003, s. 314. 
dzienne najbardziej spektakularne przejawy dysfunkcji. Wielka to zasługa dociekliwych i kompetentnych dziennikarzy.

Powszechne wśród przegranych transformacji i adekwatne do ich sytuacji poczucie upośledzenia staje się coraz silniejsze w miarę umacniania się przekonania, że innym wszystko wolno, że tak już być musi, że „oni”, ci u władzy, nie dbają o naród, tylko o siebie i swoich kolesiów, że nie liczy się nic (ani zasady moralne, ani zwykła przyzwoitość) tylko „kasa”. Umacnia to funkcjonujące w społeczeństwie przekonanie, że system społeczny jest niesprawiedliwy, a nowe reguły gry nieczyste. Normalny, porzadny człowiek niczego się $\mathrm{w}$ nim nie dorobi. Bogactwo nie wynika bowiem $z$ rzetelnej pracy, wysokich kwalifikacji czy uczciwego wykonywania obowiązków, ale jest efektem przestępstwa, malwersacji czy korupcji. Szczególnie wtedy, kiedy przekonania społeczeństwa sa bliskie realiom: wieloszczeblowej patologii władzy.

Skutkiem tego stanu rzeczy jest psucie państwa w wymiarze społecznym, politycznym i administracyjnym. Mirosława Marody i Jerzy Hausner określaja to zjawisko pojęciem instytucjonalizacji nieodpowiedzialności ${ }^{13}$. W wymiarze społecznym rodzi to powszechny „[...] brak zaufania wobec polityki i polityków, co oznacza brak obywatelskiego wsparcia dla państwa i jego działań. W wymiarze politycznym zasadniczym problemem stało się upartyjnienie państwa i jego agend, prowadzace do podporządkowania ich działań interesom jednostek i waskich, oligarchicznych grup. $Z$ kolei w wymiarze administracyjnym zasadniczym problemem jest niska sprawność aparatu administracyjnego i powszechność korupcyjnych praktyk"14.

Sa to, najogólniej rzecz ujmujacc, silnie rozpowszechnione złe standardy zachowań klasy politycznej, w których mieszaja się niekompetencja, arogancja i pazerność. Mają one klasyczne, podręcznikowe, rzec by można, cechy patologii władzy publicznej.

\footnotetext{
${ }^{13}$ J. Hausner, M. Marody (red.), Jakość rzadzenia: Polska bliżej Unii Europejskiej?, Fundacja im. Friedricha Eberta, Małopolska Szkoła Administracji Publicznej Akademii Ekonomicznej w Krakowie, Warszawa - Kraków 2000, zwłaszcza rozdz. 3: Instytucjonalizacja nie-odpowiedzialności.

${ }^{14}$ Ibidem, s. 158.
} 


\section{Grzech pierworodny rządzących: ukryty wymiar transformacji}

Do najczęściej przywoływanych przejawów patologii władzy należą niekompetencja, przedkładanie interesów partyjnych i grupowych nad interes publiczny (państwa i społeczeństwa), klientelizm, korupcja. Ta ostatnia należy do najbardziej spektakularnych wskaźników dysfunkcji władzy. Ważne jest jednak i to, że poszczególne rodzaje patologii występuja często nierozdzielnie. Świadczy o tym na przykład (zamieszczona niżej) analiza działalności rad nadzorczych spółek Skarbu Państwa.

Bardzo ważnym wskaźnikiem dysfunkcji władzy jest klientelizm. Zanim do niego przejdziemy, warto się przyjrzeć zachowaniom elit mniej nagłośnionym i rzadziej przez socjologów i politologów analizowanym.

Zacznijmy od odpowiedzialności klasy politycznej za niektóre ewidentne błędy transformacji, wynikające $z$ przeniesienia do polskiej gospodarki modelu, który od początku niezbyt dobrze do niej przystawał i zaowocował niekorzystnymi, właśnie patologicznymi następstwami. Chodzi tu, najogólniej rzecz ujmując, o przyjęty w Polsce i innych krajach postkomunistycznych praktycznie ten sam (choć mniej lub bardziej konsekwentnie wdrażany) model przekształceń własnościowych, w dużej mierze także politycznych i społecznych.

Joseph E. Stiglitz, noblista, któremu trudno odmówić znajomości mechanizmów reform ${ }^{15}$, twierdzi, że właśnie zaszczepienie modelu $z$ innej tradycji było błędem. Nie należało w sposób doktrynalny narzucać tych samych rozwiązań odmiennym krajom. Reformy nie powinny być narzucane $z$ zewnątrz, lecz aktywnie przyswajane przez kraj, jego elity i społeczeństwo. Wszystkie two-

\footnotetext{
${ }^{15}$ Jakkolwiek polscy przedstawiciele środowisk naukowych zarzucaja Stiglitzowi brak znajomości realiów krajów, o których pisze. Zob. M. Dąbrowski, S. Gomułka, J. Rostowski, Whence Reform? A Critique of the Stiglitz Perspective, "Journal of Policy Reform” 2001, t. 4, s. 339-348.
} 
rzone instytucje powinny być gospodarczo i społecznie zasymilowane, wplecione w „niewidoczną strukturę korzeni”, na którą składaja się stosunki międzyludzkie oraz elementy tradycji. Reformy będa skuteczne wtedy i tylko wtedy, kiedy elity i społeczeństwo zaczna się $z$ nimi identyfikować i je współtworzyć ${ }^{16}$. Międzynarodowi doradcy reprezentujący organizacje zagraniczne nie powinni występować w roli wszystkowiedzacych, wydajacych zunifikowane polecenia „starszych braci”. A tak w dużej mierze było, zwłaszcza w krajach niemajacych własnych, obdarzonych międzynarodowym autorytetem reformatorów.

Wszelako i przodujace w gospodarczych i społecznych reformach kraje doświadczyły „ręcznego sterowania” przez międzynarodowych doradców. Janine R. Wedel poddała wnikliwej analizie realia pomocy (finansowej, prawnej, technologicznej) państw zachodnich dla państw Europy Środkowej i Wschodniej, zwłaszcza dla Polski, Czech i Rosji ${ }^{17}$. Interesowała ja odpowiedź na fundamentalne pytanie: w jakiej mierze pomoc ta przyczyniła się do budowy gospodarki rynkowej i demokratycznych państw, w jakiej zaś stworzyła przesłanki dla utrwalenia nomenklaturowych układów interesów sprzed 1989 roku? Punktem wyjścia oceny realizacji programów pomocy był głównie wskaźnik wydanych pieniędzy. Przywoływana autorka stwierdziła, że - zgodnie $z$ dogmatycznie przeniesiona na grunt krajów Europy Wschodniej doktryna - najważniejsza była prywatyzacja, $z$ reguły przeprowadzana bez strategicznych planów i dostosowań do miejscowych warunków.

Odrębna, choć rzutujaccą na niepowodzenie transformacji kwestia byli zachodni doradcy, czyli „konsultanci kapitalizmu”. Cho-

\footnotetext{
${ }^{16}$ Zob. J.E. Stiglitz, Scan Globally, Reinvent Locally. Knowledge Infrastructure and the Localization of Knowledge, First Global Development Network Conference, Bonn, grudzien 1999 oraz idem, Whither Reform? Ten Years of Transition, w: B. Pleskovic, J.E. Stiglitz (red.), Annual World Bank Conference on Development Economics 1999, The World Bank, Washington D.C 2000, s. 27-56; zob. także G.W. Kołodko, Globalizacja - zacofanie - rozwój, w: J. Gardawski, J. Polakowska-Kujawa (red.), Globalizacja. Gospodarka. Praca. Kultura, Szkoła Główna Handlowa, Warszawa 2003.

${ }_{17}$ Zob. J.R. Wedel, Collision and Collusion. The Strange Case of Western Aid to Eastern Europe, Palgrave, New York 2001.
} 
dzi tu o głównego ideologa Jeffreya Sachsa, i związanych $z$ nim specjalistów, którzy powtarzali te same lekcje przebudowy gospodarki w kolejnych krajach dawnego obozu sowieckiego. Dotyczy to jednak także silnej grupy przedstawicieli firm konsultingowych, wybierajacych i wyceniajacych przedsiębiorstwa do sprywatyzowania, formułujących główne tezy (bądź narzucających gotowe sformułowania) projektów aktów prawnych. Często jawnie dla Polski niekorzystnych ${ }^{18}$.

Warto przytoczyć obrazowy opis tych zaszłości. Jak pisze Daniel Wincenty: „[...] osobna grupę konsultantów stanowiła tzw. Brygada Marriotta (od nazwy hotelu, w którym najczęściej zamieszkiwali w Warszawie). Owi konsultanci dzień-tu-dzień-tam (fly-in fly-out consultants) cechowali się zazwyczaj żenująca niewiedzą o specyficznych warunkach ekonomiczno-społecznych w krajach postkomunistycznych. Niemniej jednak byli świetnie opłacani i dopóki pomoc koncentrowała się w Polsce, Czechach i na Węgrzech, przez dłuższy czas można było zaobserwować ich przepływ w trójkącie Warszawa - Praga - Budapeszt"19.

Układ ten był wyjątkowo groźny dla przekształcających się państw, ponieważ owi zachodni aktorzy transformacji identyfikowali się $z$ instytucjami krajów, $z$ których się wywodzili, i wobec nich byli lojalni, często kosztem strategicznego interesu państwa, któremu doradzali. W krańcowych przypadkach wyrażało się to $\mathrm{w}$ działaniach na granicy prawa (szpiegostwo przemysłowe).

Ten pesymistyczny obraz mechanizmu transformacji podzielaja nieliczni raczej autorzy. Na szczególna uwage zasługują rozważania Judith M. Green. Jej zdaniem „pomoc, jaka faktycznie USA zaproponowały [...] obrazuje [...] niebezpieczna wręcz nieświadomość specyficznych aspektów polskiej historii, kultury oraz wspó1czesnej sytuacji połączona $z$ nieuprawnionym założeniem, iż model amerykańskich politycznych, kapitalistycznych instytucji ekono-

\footnotetext{
${ }^{18}$ Szerzej o niebezpieczeństwach związanych $\mathrm{z}$ ingerencja $\mathrm{w}$ polskie prawo zob. A. Zybertowicz, W uścisku tajnych służb... .

${ }^{19}$ D. Wincenty, Transformacja, prywatyzacja i czołowi aktorzy, „Studia Polityczne” 2002, nr 13.
} 
micznych [...] reprezentuje ostateczną fazę rozwoju demokracji, do której dążyć powinny wszystkie inne kraje, łącznie z Polska"”20.

Ukryci zachodni aktorzy transformacji kreowali (lub wzmacnia1i) pozycje silnej i wpływowej grupy lokalnych przewodników owych zachodnich instytucji finansowych. Rekrutowali się oni $z$ reguły $z$ elit postkomunistycznych i $z$ dawnej opozycji, a ich kapitał początkowy to sieć wcześniejszych (datujących się $z$ okresu ancien regime’u) kontaktów $\mathrm{z}$ mniej lub bardziej prominentnymi ludźmi Zachodu. Nowi aktorzy transformacji działali za pośrednictwem różnego rodzaju fundacji i organizacji pozarzadowych. $Z$ czasem grupa ta spotężniała, $z$ niej też wyłonili się późniejsi decydenci życia gospodarczego i politycznego, czyli ludzie, których dłuższa działalność na styku państwowe-prywatne niekoniecznie skłaniała do przedkładania interesów publicznych nad interesy własne. Można zaryzykować twierdzenie, że ta właśnie grupa stanowiła podstawowy trzon późniejszej elity władzy (ze wszystkimi gospodarczymi i politycznymi sukcesami i błędami rządów owych elit w rozmaitych konfiguracjach koalicyjnych).

W rezultacie tych zaszłości żyjemy w nieco dziwnym państwie. Jest to fenomen złożony, którego część funkcjonuje zgodnie z klasycznym modelem wolnorynkowym, część zaś w sposób odmienny, według dawno minionych wzorców gospodarki zdalnie sterowanej. Państwo polskie 2004 roku jest zatem instytucja działająca według wzajemnie sprzecznych zasad, co samo w sobie jest dysfunkcjonalne. Według Andrzeja K. Koźmińskiego mamy do czynienia $z$ „tworem wewnętrznie sprzecznym, ponieważ z jednej strony kontynuuje odziedziczona po poprzedniej formacji rolę "właściciela", "zarządcy", "redystrybutora" i "rozdzielcy", $z$ drugiej zaś wyzbyło się kontroli nad zasobami, tworząc "fundusze", "agencje", "zarządy", kasy itp., które po kolejnych wyborach wchodza do puli łupów politycznych"21.

\footnotetext{
${ }^{20}$ J.M. Green, Pogkębianie demokracji $w$ Europie Środkowej: perspektywa radykalnego pragmatyzmu opartego o doświadczenia amerykańskie, w: J. Miklaszewska (red.), Demokracja w Europie Środkowej, 1989-1999, Instytut Studiów Strategicznych, Kraków 2001, s. 109-110. ${ }^{21}$ A.K. Koźmiński, Jaki kapitalizm dla Polski?, w: Polski ustrój społeczno-gospodarczy. Jaki kapitalizm?, Rada Strategii Gospodarczej przy Radzie Ministrów, Warszawa 2003 (Raport nr 22), s. 26.
} 
Nie ulega watpliwości, że w tych warunkach nie da się realizować żadnej spójnej polityki gospodarczej pro publico bono, relatywnie łatwo jest natomiast zawłaszczać środki publiczne, kierując się politycznym klientelizmem oraz interesami grupowymi i partyjnymi.

Istnieje także druga, społeczna, strona przeszczepienia do Polski modelu obcego kulturowo. Ów przeszczep nie mógł się przyjać w kraju o odmiennych tradycjach historycznych, politycznych i o innej mentalności obywateli. Jerzy Szacki, piszacc o „imitacyjnym modelu transformacji” uważa, że „ów schemat zawierał [...] przyjęte milczaco założenie, iż ludzie w naturalny niejako sposób skłonia się do gospodarki rynkowej i liberalnej demokracji, jeśli zaś fakty świadcza na razie o czymśs przeciwnym, nie dowodzi to $\mathrm{w}$ istocie niczego innego poza tym, że zostali przejściowo ogłupieni przez socjalistyczna ideologię lub długotrwałe życie w warunkach realnego socjalizmu"22.

$\mathrm{W}$ rezultacie wprowadzanie $\mathrm{w}$ życie nowego systemu zderzyło się $z$ oporem materii społecznej, co zaowocowało tym, że mechanizm zmiany gospodarki nie do końca zadziałał, tworzac $\mathrm{w}$ istocie system niejednorodny (zawierajacy elementy przeciwstawnych sektorów - starego i nowego), który Wacław Wilczyński nazywa „dualizmem systemowym”23.

Tego rodzaju sytuacja doprowadziła do wielowymiarowych konsekwencji. Jedna $z$ nich jest to, że prawna regulacja planowania, zarzadzania i kontroli podstawowych dla transformacji procesów stanowi swoiste odzwierciedlenie owego dualizmu systemowego. Jest ona niespójna, niekonsekwentna i patogenna. Na przykład: do połowy października 2002 roku nie ogłoszono jednolitego tekstu ustawy prywatyzacyjnej. ,Jej czytelność - pisze Cezary Kosikowski - była więc tak mocno utrudniona, iż czytelnik ustawy nie

\footnotetext{
${ }^{22}$ J. Szacki, Nauki społeczne wobec wielkiej zmiany, w: J. Kurczewska (red.), Zmiana społeczna. Teorie i doświadczenia polskie, Instytut Filozofii $i$ Socjologii PAN, Warszawa 1999, s. 131.

${ }^{23}$ Zob. W. Wilczyński, Pięć lat polskiej transformacji 1989-1994, w: Pięć lat po czerwcu (praca zbiorowa), Centrum im. Adama Smitha, Warszawa 1994, s. 43 i nast.
} 
miał całkowitej pewności, czy i w jakim stopniu obowiąuja jej poszczególne przepisy"24. Wpływ kiepskiego prawa na dynamikę przemian jest oczywisty, podobnie jak jego zakotwiczenie w niejasnym, dwoistym systemie transformacji.

${ }^{24}$ C. Kosikowski, Prawne aspekty prywatyzacji w Polsce, w. M. Jarosz (red.), Pułapki prywatyzacji, Instytut Studiów Politycznych PAN, Warszawa 2003, s. 41. 